\title{
TRAFFICKING: \\ SISI BURAM MIGRASI INTERNASIONAL
}

\author{
Thohir Yuli Kusmanto
}

Pengamat Migrasi dan Demografi

email: tohiryuli@yahoo.co.id

\begin{abstract}
Abstrak
Migrasi internasional akan selalu berlangsung sampai kapanpun. Modernisasi dengan kemajuan teknologi transportasi dan informasi berpengaruh sangat signifikan bagi meningkatnya volume migran. Banyak faktor yang mendorong orang untuk bermigrasi, diantaranya; politik, agama, pendidikan, psikologis dan ekonomi. Faktor ekonomi merupakan yang paling dominan. Kesejahteraan hidup merupakan tujuan utama mayoritas orang bermigrasi. Segala cara seringkali dilakukan para migran agar bisa mencapai daerah tujuan dan mendapatkan pekerjaan. Cara legal dan atau ilegal seringkali harus ditempuh. Mereka yang menggunakan cara legal akan merasa lebih aman dan nyaman di negara tujuannya. Namun demikian, mereka harus menempuh prosedur yang rumit dan biaya yang mahal. Kondisi ini membuat banyak orang yang menempuh cara-cara ilegal. Akibatnya banyak yang terjebak dalam mafia internasional yang meraup keuntungan dari semangat bermigrasi orang-orang yang tidak mau dan mampu menempuh cara legal. Mafia pekerja internasional seringkali mengarahkan migran masuk dalam pasar hitam dunia kerja. Mereka diperdagangkan (trafficking) untuk menjadi budak, bekerja secara sembunyi-sembunyi, pekerja seks komersial, dan pekerja anak-anak dengan resiko tinggi. Mafia kerja tersebut memanfaatkan kelemahan-kelemahan para migran, diantaranya: minimnya pendidikan, minimnya keterampilan, kelemahan fisik (karena perempuan dan anak), mereka yang terjebak utang dan lain-lain. Realitas ini menjadi setali tiga uang karena mayoritas pekerja migran adalah perempuan. Indonesia termasuk negara yang jumlah pekerja migrannya cukup banyak di dunia, dan pekerja migran perempuan selalu paling banyak setiap tahunnya.
\end{abstract}

Kata Kunci: migrasi, trafficking, pekerja migran, perempuan 


\section{A. Pendahuluan}

Migrasi internasional merupakan fenomena yang selalu aktual dalam sejarah peradaban manusia. Fenomena ini merupakan penjelasan atas sistuasi kehidupan manusia yang terhubung satu dengan yang lain. Meningkatnya volume migrasi dalam masyarakat modern yang telah terglobalisasi, merupakan pertanda telah memudarnya atau terbukanya isolasi-isolasi sosial, budaya, ekonomi dan politik global. Implikasi selanjutnya adalah terjadinya proses peleburan batas identitas sosial-budaya dan politik ke dalam sistem yang dikenal dengan istilah union system atau paralaysation (Nedelmann, 1991). ${ }^{1}$

Sejarah modern dari migrasi internasional dapat dibagi menjadi empat periode. Pertama, selama periode dagang, dari sekitar 1500-1800, dunia imigrasi didominasi oleh arus keluar Eropa dan berasal dari proses kolonisasi dan pertumbuhan ekonomi di bawah pedagang kapitalisme. Selama 300 tahun, Eropa datang menghuni sebagian besar dari Amerika, Afrika, Asia, dan Oceania (Tinker 1995; Lucassen 1995, Altman 1995; Heffernan 1995). Periode kedua, industri emigrasi dimulai pada awal abad ke-19 dan berasal dari pembangunan industri di Eropa dan penyebaran kapitalisme ke bekas koloni di Dunia Baru (Hatton dan Williamson 1998). Pentingnya emigrasi dalam sejarah ekonomi Eropa bisa dilihat pada Tabel 1, yang menyajikan jumlah imigran antarbenua dari Eropa dan Jepang selama periode 1846-1924 (lihat Massey 1988). Selama periode awal industrialisasi, sejumlah 48 juta emigran meninggalkan benua Eropa, jumlah yang mewakili sekitar $12 \%$ dari penduduk Eropa pada pergantian abad. ${ }^{2}$

Periode ketiga; pada akhir abad ke-19 dan awal abad ke-20, merupakan periode pertama dari globalisasi ekonomi, ditandai dengan arus besar modal, bahan baku, dan sirkulasi barang antara Eropa, Amerika, Asia, dan Pasifik. Ekonomi global memperluas gerak penduduk dalam jumlah

${ }^{1}$ Lihat dalam Abdul Haris, Gelombang Migrasi dan Jaringan Perdagangan Manusia (Yogyakarta: Pustaka Pelajar, 2005), hlm. 94.

${ }^{2}$ Douglas S. Massey, "Patterns and Processes of International Migration in the 21st Century", Paper prepared for Conference on African Migration in Comparative Perspective, Johannesburg, South Africa, 4-7 June, 2003, hlm. 1. 
banyak, berakar pada transformasi struktural yang melampaui negaranegara Eropa, karena industri mereka masuk ke dalam rezim perdagangan global. Selama era pertama globalisasi, emigran Eropa pergi ke sebagian wilayah bekas koloni Eropa yang mengalami pergolakan industrialisasi dan pembangunan yang pesat.

Periode keempat, pasca-industri migrasi muncul selama pertengahan tahun 1960-an dan merupakan istirahat tajam dengan masa lalu. Bukannya didominasi oleh arus keluar dari Eropa ke beberapa masyarakat pemukim, imigrasi menjadi benar-benar dalam lingkup global, seperti jumlah dan berbagai negara sebagai pengirim dan penerima meningkat, dengan pasokan imigran global bergeser dari Eropa ke negara-negara berkembang dari Dunia Ketiga (Castles dan Miller 1993). Sedangkan migrasi selama era industri membawa orang-orang dari padat menetap, menetap ke negaranegara industrialisasi yang cepat menuju ke jarang, migrasi di era pasca industri membawa orang-orang dari negara padat mapan dalam tahap awal industrialisasi menuju masyarakat padat mapan pasca industri. ${ }^{3}$

Secara konseptual migrasi adalah perubahan tempat tinggal permanen atau semipermanen, yang lebih bermakna, mungkin sebagai transfer spasial dari satu unit sosial atau lingkungan yang lain, yang menekan atau mengurai ikatan sosial sebelumnya. ${ }^{4}$ Dalam konteks tulisan ini migrasi internasional merupakan suatu proses perpindahan penduduk kontemporer yang mengandung pengertian orientasi dan jarak perpindahan penduduk. Pada mulanya orientasi migrasi internasional semata-mata ekonomi dan jangkauan jaraknya pendek. Pada masa kontemporer orientasinya lebih kompleks dan jangkauan jaraknya lebih jauh atau luas. Faktor yang menentukan perubahan tersebut adalah keberhasilan individu atau kelompok membangun hubungan-hubungan yang melampaui jarak ekonomi, sosial, budaya dan politik. ${ }^{5}$

\footnotetext{
${ }^{3}$ Douglas S. Massey, “Patterns and Processes of International Migration...," hlm. 3.

${ }^{4}$ Lihat dalam The Hypothesis of the Mobility Transition Author(s): Wilbur Zelinsky, Source: Geographical Review, Vol. 61, No. 2 (Apr., 1971), hlm. 224.

${ }^{5}$ Abdul Haris, Gelombang Migrasi..., hlm. 94-95.
} 
Diantara orientasi yang kompleks dari migrasi aspek ekonomi tetap dominan. Secara ekonomi migran menjadi pekerja di luar negaranya. Data Organisasi Perburuhan Internasional (International Labour Organization/ ILO) menemukan beberapa fakta tentang migrasi kerja internasional diantaranya; terdapat sekitar 105 juta pekerja migran yang tinggal di luar negara asal mereka, dengan tingkat pertumbuhan persentase perempuan yang besar (hingga 50 persen). Diperkirakan sekitar 30 juta (atau sekitar 30\%) pekerja migran di Asia (data tahun 2010). Jumlah perempuan di kalangan pekerja migran dari Asia terus meningkat, dan diperkirakan mencapai antara 60 dan 80 persen. Sekitar 53 juta pekerja migran bekerja sebagai pekerja rumah tangga (PRT) di seluruh dunia pada 2010; setengah dari jumlah keseluruhan PRT ini berada di Asia. Pekerjaan rumah tangga masih menjadi sektor yang sangat didominasi perempuan: kaum perempuan mencapai 83 persen dari jumlah keseluruhan PRT. Pekerjaan rumah tangga menjadi salah satu sumber lapangan kerja terpenting bagi kaum perempuan Asia yang pergi melewati batas negara mereka. ${ }^{6}$

Kepentingan ekonomi dari fenomena migrasi internasional ada dua kategori secara hukum yaitu ekonomi legal dan ilegal. Ekonomi legal menunjuk pada proses ekonomi yang bersifat formal kontraktual. Ekonomi ilegal bersifat informal nonkontraktual. Trafficking merupakan bagian yang sangat menonjol dalam ekonomi informal nonkontraktual diantara perdagangan narkoba dan senjata. Fenomena trafficking merupakan sesuatu yang bersifat global (tidak hanya menjadi ciri negara-negara berkembang). Terjadinya trafficking berakar pada ketidakberdayaan migran dalam memasuki pasar komiditas tenaga kerja dan faktor sosial politik lainnya. Merujuk data ILO di atas maka diantara migran yang tidak berdaya dalam arus global trafficking adalah perempuan dan anak. Mereka menjadi migran yang rentan untuk menjadi komoditas trafficking. Kerentanan tersebut disebabkan oleh faktor relasi sosial dan budaya yang melemahkan posisi keduanya

${ }^{6}$ Lihat dalam International Labour Organization (ILO), Jakarta, 10 Tahun menangani migrasi kerja di Indonesia, http://www.ilo.org/wcmsp5/groups/public/--asia/--ro-bangkok/-ilo-jakarta/documents/publication/wcms_213360.pdf , unduh Selasa, 24 Desember 2013, jam 05.54. 
dalam masyarakat global. Namun demikian bukan berarti migran korban trafficking adalah perempuan dan anak.

\section{B. Trend dan Volume Migrasi Internasional}

Sebagaimana sejarah migrasi yang dijelaskan Masey (2003) di atas, bahwa migrasi internasional selalu mengalami perubahan-perubahan arah, kondisi sosial ekonomi menjadi aspek yang menentukan kecenderungan perubahan tersebut. Sebagai gambaran pada tahun 1980-an negara-negara di Eropa selatan misalnya; Italia, Spanyol, dan Portugal yang hanya satu dekade menjadi negara yang mengirim migran ke negara-negara kaya di utara. Pertumbuhan ekonominya yang membaik menyebabkan mereka berubah menjadi negara tujuan migran luar negeri. Mereka mulai mengimpor pekerja dari Afrika, Asia, dan Timur Tengah. Pada saat yang sama, Jepang yang mengalami kondisi penurunan (rendahnya) tingkat kelahiran dan akan terus menurun, diikuti dengan terjadi penuaan penduduk, dan standar hidup tinggi, menjadikan negara ini segera mengalihkan perhatiannya kepada migran dari negara-negara miskin di Asia dan bahkan Amerika Selatan untuk memenuhi kebutuhan tenaga kerja. ${ }^{7}$

Migrasi internal dan internasional dapat dijelaskan berdasarkan pada tingkat banyak sedikit orang yang terlibat di dalamnya. Untuk menyebut situasi ini maka penulis menggunakan istilah volume migrasi. Ada beberapa faktor yang menentukan volume migrasi internal dan internasional ditentukan oleh beberapa faktor: ${ }^{8}$

1. Faktor politik; berhubungan dengan sistem birokrasi dan prosedur yang harus dilewati seorang migran dalam proses bermigrasi. Mudahnya sistem birokrasi dan sederhananya prosedur yang harus dihadapi oleh migran akan meningkatkan volume migrasi. Kondisi sebaliknya jika birokrasi dan prosedur sulit maka akan menurunkan volume migrasi.

${ }^{7}$ Lihat dalam Theories of International Migration: A Review and Appraisal, Author(s): Douglas S. Massey, Joaquin Arango, Graeme Hugo, Ali Kouaouci, Adela Pellegrino, J. Edward Taylor, Source: Population and Development Review, Vol. 19, No. 3 (Sep., 1993), p. 431.

${ }^{8}$ Abdul Haris, Gelombang Migrasi..., hlm. $90-91$. 
2. Faktor ekonomi; meliputi latar belakang ekonomi migran, biaya migrasi dan upah yang akan diperoleh di tempat tujuan.

3. Faktor aksesibilitas; yang meliputi aksesibilitas transportasi dan jarak migrasi. Ketersediaan dan terjangkaunya biaya transportasi yang menghubungkan antara daerah asal migran dengan tujuan migran akan meningkatkan volume migrasi. Hal tersebut semakin meningkat jika dihubungkan dengan jarak antar keduanya yang relatif dekat.

Diantara faktor yang mempengaruhi volume migrasi tersebut faktor ekonomi merupakan faktor yang dominan pengaruhnya. Kondisi ekonomi di daerah asal migran yang tidak mencukupi untuk memenuhi kebutuhan hidupnya atau sekedar untuk survive, menjadi pendorong utama terjadinya migrasi. Pilihan untuk mencari daerah lain yang secara ekonomi lebih baik sebagai tujuan migrasi, merupakan sebuah pilihan rasional. Sesuatu yang wajar jika seseorang mengharapkan hidupnya lebih baik, meskipun ia harus bermigrasi.

Migrasi internasional dipengaruhi juga oleh faktor ekonomi. Globalisasi telah membawa konsekuensi-konsekuensi secara langsung dalam bidang ekonomi di berbagai negara. Adanya semangat globalisasi telah menyebabkan terjadinya ekspansi sistem kapitalisme global yang menciptakan sistem dualisme pasar kerja (Lash dan John Urry, 1994). ${ }^{9}$ Sistem dualisme pasar kerja tersebut dapat dijelaskan sebagai berikut:

1. Sistem kapitalisme global telah membuka peluang kerja yang lebih luas tanpa mempertimbangkan identitas nasional tertentu.

2. Sistem kapitalisme global pada sisi yang lain menutup kemungkinan masuknya pekerja-pekerja kurang terampil ke dalam kompetisi pasar yang telah diciptakannya. Dimensi kedua inilah yang menjadi sebab terjadi atau berkembangnya pasar gelap tenaga kerja (labour black market).

Adanya pasar gelap tenaga kerja, menjadi lahan subur bagi terjadinya trafficking. Banyak migran yang terjerat jaringan mafia tenaga kerja yang mengendalikan pasar gelap tersebut. Kuatnya jaringan mafia tenaga kerja di pasar gelap tersebut menyebabkan migran yang sudah terjebak di dalamnya

\footnotetext{
${ }_{9}^{9}$ Abdul Haris, Gelombang Migrasi..., hlm. 91.
} 
sulit untuk keluar. Bahkan institusi sekelas negara pun seringkali tidak berdaya menghadapi jaringan mafia tersebut.

Indonesia merupakan bagian dari negara yang memiliki buruh migran yang cukup banyak di dunia ini, tersebar di beberapa negara. Pada tahun 2011, berdasarkan data dari Badan Nasional Penempatan dan Perlindungan Tenaga Kerja Indonesia (BNP2TKI); ada sekitar 3,8-4 juta pekerja migran Indonesia yang bekerja di luar negeri. Pada tahun yang sama ada sekitar 581.081 pekerja migran Indonesia yang berangkat ke luar negeri. Ada 5 negara tujuan terbesar yaitu; Malaysia, Taiwan, Hong Kong, Singapura, Arab Saudi. Kebanyakan dari mereka adalah perempuan yang bekerja sebagai pekerja rumah tangga (lihat data BNP2TKI di 2010, 2011. Ada penurunan sedikit di 2012 namun angka pekerja "informal" masih signifikan). ${ }^{10}$ Sebagai gambaran nyata dapat dilihat dalam tabel berikut:

Tabel 1.

Jumlah TKI pada Sektor Formal dan Informal yang Dilayani BNP2TKI Tahun 2006 - 2012

\begin{tabular}{|c|c|c|c|c|c|c|}
\hline No. & Tahun & $\begin{array}{c}\text { Jumlah TKI yang } \\
\text { Dilayani }\end{array}$ & TKI Formal & $\%$ & $\begin{array}{c}\text { TKI } \\
\text { Informal }\end{array}$ & $\%$ \\
\hline 1 & 2006 & 680.000 & 177.495 & 26 & 502.505 & 74 \\
\hline 2 & 2007 & 696.746 & 196.191 & 28 & 500.555 & 72 \\
\hline 3 & 2008 & 644.731 & 182.439 & 29 & 462.292 & 71 \\
\hline 4 & 2009 & 632.172 & 103.918 & 17 & 528.254 & 83 \\
\hline 5 & 2010 & 575.804 & 124.683 & 27 & 451.121 & 73 \\
\hline 6 & 2011 & 581.081 & 264.756 & 46 & 316.325 & 54 \\
\hline 7 & 2012 s.d & 362.510 & 188.765 & 52 & 173.745 & 48 \\
\hline
\end{tabular}

Sumber Data: Pusat Penelitian Pengembangan Dan Informasi (PUSLITFO) BNP2TKI

${ }^{10}$ Lihat dalam Albert Bonasahat, S.H., LL.M., ILO Jakarta, Briefing Jurnalis: Catatan Akhir Tahun Perlindungan Pekerja Migran, http://www.ilo.org/wcmsp5/groups/public/--asia/--robangkok/--ilo-jakarta/documents/presentation/wcms_201585.pdf unduh Rabu, 25 Desember 2013, jam 07.05. 
Berdasarkan data dalam tabel di atas maka bisa dilihat bahwa prosentase terbesar tenaga kerja Indonesia di luar negeri bekerja di sektor informal. Selisihnya cukup signifikan dengan mereka yang bekerja di sektor formal terutama antara tahun 2006-2011. Pada tahun 2012 sampai dengan bulan September pekerja migran mengalami penurunan. Komposisi formalinformal mengalami perubahan pula. Pekerja formal lebih banyak (52 \%), sedangkan pekerja informal lebih sedikit (48\%).

Data BNP2TKI tersebut jika dipilah berdasarkan jenis kelamin pekerja menunjukkan bahwa pekerja migran Indonesia didominasi pekerja dengan jenis kelamin perempuan. Kondisi tersebut tentu menggambarkan bahwa pekerja migran perempuan lebih mudah terserap dilapangan kerja. Kemudahan tersebut tentu ada beberapa faktor yang mempengaruhinya; sektor pekerjaannya membutuhkan tenaga perempuan, perempuan lebih mudah untuk dipekerjakan, perempuan lebih murah upahnya, dan perempuan lemah posisi tawarnya. Semua faktor tersebut bisa jadi menunjukkan adanya bias gender dalam penempatan TKI di luar negeri. Sebagai gambaran yang lebih jelas tentang kompisis pekerja migran berdasarkan jenis kelamin bisa dilihat dalam tabel berikut:

Tabel 2.

Jumlah TKI yang Dilayani BNP2TKI

Berdasarkan Jenis Kelamin Tahun 2006 - 2012

\begin{tabular}{|c|c|c|c|c|c|c|}
\hline No. & Tahun & $\begin{array}{c}\text { Jumlah TKI } \\
\text { yang Dilayani }\end{array}$ & Perempuan & $\%$ & Laki-laki & $\%$ \\
\hline 1 & 2006 & 680.000 & 542.000 & 80 & 138.000 & 20 \\
\hline 2 & 2007 & 696.746 & 543.859 & 78 & 152.887 & 22 \\
\hline 3 & 2008 & 644.731 & 496.131 & 76 & 148.600 & 24 \\
\hline 4 & 2009 & 632.172 & 528.984 & 83 & 103.188 & 17 \\
\hline 5 & 2010 & 575.804 & 451.120 & 78 & 124.684 & 22 \\
\hline 6 & 2011 & 581.081 & 373.373 & 64 & 207.708 & 36 \\
\hline 7 & 2012 s.d & 362.510 & 206.689 & 57 & 155.821 & 43 \\
\hline
\end{tabular}

Sumber Data: Pusat Penelitian Pengembangan Dan Informasi (PUSLITFO) BNP2TKI 
Mendasarkan data tabel tersebut yang menunjukkan bahwa pekerja migran Indonesia didominasi perempuan, kondisi ini menggambarkan potensi terjadinya trafficking. Posisi tawar yang lemah bagi pekerja perempuan di pasar tenaga kerja global, menyebabkannya rentan menghadapi masalah ditempat kerja. Ketika mereka mengalami masalah potensial untuk terjerat mafia tenaga kerja ilegal, dan mudah menjadi komoditas bagi trafficker.

\section{Faktor Penyebab Trafficking}

Perdagangan orang (trafficking) merupakan serangkain proses perekrutan, pengiriman, pemindahan, penampungan, atau penerimaan orang, dengan cara ancaman, penggunaan kekerasan atau cara pemaksaan lain, penculikan, penipuan, tipu daya, atau penyalahgunaan kekuasaan atau atas posisi rentan seseorang dalam rangka untuk mendapatkan atau menerima atau pemberian pembayaran. Pada orang yang memegang kendali atas orang lain, untuk tujuan eksploitasi. " (Pasal 3 Protokol PBB untuk Mencegah, Menekan dan Menghukum Perdagangan Manusia, khususnya Perempuan dan Anak, Melengkapi Konvensi PBB Menentang Kejahatan yang Teroganisir Lintas Negara). ${ }^{11}$ Namun demikian trafficking bukan merupakan masalah lintas negara saja. Ia bisa berlangsung internal suatu negara.

Meratifikasi protokol PBB tersebut maka pemerintah Republik Indonesia menetapkan Undang-Undang Republik Indonesia Nomor 21 Tahun 2007 tentang Pemberantasan Tindak Pidana Perdagangan Orang. Dalam Bab I Ketentuan Umum Pasal 1 dijelaskan bahwa perdagangan orang adalah tindakan perekrutan, pengangkutan, penampungan, pengiriman, pemindahan, atau penerimaan seseorang dengan ancaman kekerasan, penggunaan kekerasan, penculikan, penyekapan, pemalsuan, penipuan, penyalahgunaan kekuasaan atau posisi rentan, penjeratan utang atau memberi bayaran atau manfaat, sehingga memperoleh persetujuan dari orang yang memegang kendali atas orang lain tersebut, baik yang dilakukan di

11 Counter-Trafficking; IOM's Approach, lihat dalam http://www.iom.int/cms/ countertrafficking jam 17.45, 13 Juni 2013. 
dalam negara maupun antar negara, untuk tujuan eksploitasi atau mengakibatkan orang tereksploitasi. ${ }^{12}$

Trafficking merupakan istilah kontemporer dari adanya praktik-praktik perbudakan dalam ruang migrasi internasional. Trafficking dalam istilah perbudakan merupakan yang telah berlangsung lama (ribuan tahun) dalam sejarah peradaban manusia. Pada masa lalu (sebelum modernisasi) perbudakan terjadi sebagai bagian dari kesuksesan suatu kelompok masyarakat (klan, suku atau kerajaan/kekaisaran) dalam menaklukkan suatu wilayah dan pelebaran kekuasaan atas dasar kekuatan dominan. Proses tersebut telah mengarah pada suatu pola dikotomis dari suatu fungsi dan peran sosial, ekonomi dan politik yang bermuara pada model-model penguasaan dan pemilikan oleh kelompok dominan terhadap kelompok lemah. Kelompok dominan yang berhasil menaklukkan kelompok yang lemah mendapatkan konsesi pembayaran dalam bentuk pengabdian mutlak kepada mereka. ${ }^{13}$ Dalam kerangka inilah perbudakan pada masa lalu dibangun.

Jaman modern tidaklah mampu menghapus sistem perbudakan tersebut. Fenomenanya hanya mengalami pergeseran yang cukup mendasar. Kelompok dominan yang menguasai kelompok yang lemah bukan lagi berwujud kelembagaan politik atau kepemilikan kekuatan militer/fisik. Mereka telah berubah bentuk menjadi rezim ekonomi dan kapitalisme ${ }^{14}$. Ekonomi kapitalistik telah merekonstruksi perbudakan (trafficking) ke dalam sistem sosial yang tidak disadari oleh masyarakat. Orientasinya tentu untuk menumpuk keuntungan yang lebih rasional. Bentuk-bentuknya berupa pemanfaatan tenaga kerja yang didasarkan pada kepentingan ekonomi dan politik, yang proses pemanfaatannya mengarah pada perbudakan. ${ }^{15}$

${ }^{12}$ Lihat dalam Undang-undang Republik Indonesia Nomor 21 tahun 2007 tentang Pemberantasan Tindak Pidana Perdagangan Orang.

${ }^{13}$ Undang-undang Republik Indonesia Nomor 21 tahun 2007..., hlm. 116.

${ }^{14}$ Undang-undang Republik Indonesia Nomor 21 tahun 2007..., hlm. 116-117.

${ }^{15}$ Undang-undang Republik Indonesia Nomor 21 tahun 2007..., hlm. 119. 


\section{Kondisi Trafficking Global dan Internal Indonesia}

Data yang dikumpulkan langsung dari orang yang diperdagangkan, seperti dalam pendekatan IOM, merupakan sumber penting dari informasi dan menjadi bukti utama dalam upaya untuk memahami dan memerangi perdagangan manusia. Penelitian dan pengumpulan data yang dilakukan dalam rangka bantuan, seperti pendekatan IOM, dapat dapat menjelaskan dengan terang pada berbagai isu termasuk risiko dan faktor kerentanan, kebutuhan berbagai kelompok korban trafficking (misalnya laki-laki, perempuan, anak-anak, korban tenaga kerja dan perdagangan seks); perdagangan dalam dimensi gender, rincian dari proses perdagangan dan, meskipun hal itu pada tingkat lebih rendah, pelaku yang terlibat, modus operandi mereka, dipilih untuk digunakan dan sebagainya (Surtees \& Craggs, 2010). ${ }^{16}$

Pada tahun 2011 The International Organization for Migration menangani kasus trafficking sebanya 5498 kasus. Dari sejumlah kasus tersebut, mereka yang menjadi korban trafficking memiliki beragam persoalan. Diantaranya diperdagangkan untuk tujuan kerja paksa (53\%), eksploitasi seksual (27\%), tujuan lain seperti kawin paksa dan perdagangan organ (7\%), mengemis (5\%), kombinasi pekerja seksual \& tenaga buruh (5\%), tujuan yang tidak diketahui (3\%), dan untuk kerja paksa dan lainnya serta untuk tingkat kegiatan kriminal rendah (0,1\%). Berdasarkan area migrasi yang dilakukan oleh orang-orang korban trafficking umumnya diperdagangkan melintasi perbatasan (64\%), internal negara (31\%), dan keduanya (melintasi perbatasan dan internal negara) sebanyak $1 \%$. Jenis perdagangan yang tidak diketahui ada empat persen (4\%). ${ }^{17}$

Sejumlah kasus trafficking global yang ditangani IOM tersebut secara region tersebar di seluruh dunia. Berdasarkan region yang ada, fenomena

${ }^{16}$ Lihat dalam “Iom 2011case Data on Human Trafficking: Global Figures \& Trends," The data in this document was complied by IOM Headquarters staff, Anvar Serojitdinov, Project Officer, aserojitdinov@iom.intin conjunction with the assistance of IOM field missions.All enquiries can be addressed to the given email address or directly to the appropriate IOM mission, hlm. 5 .

17 “Iom 2011case Data on Human Trafficking: Global Figures \& Trends,"..., hlm. 6. 
trafficking tidak hanya menjadi persoalan negara-negara berkembang. Banyak kasus yang terjadi di region negara-negara maju, dalam hal ini Eropa. Untuk lebih jelasnya berikut proporsi kasus trafficking berdasarkan region global.

Tabel 3.

Kasus Trafficking yang Ditangani IOM Tahun 2011

Berdasarkan Region

\begin{tabular}{|c|c|}
\hline Region & Jumlah Kasus \\
\hline Africa & 303 \\
\hline South \& Central Asia & 1049 \\
\hline East Asia \& pacific & 860 \\
\hline Europe & 1606 \\
\hline Near East & 696 \\
\hline Western Hemisphere & 984 \\
\hline GLOBAL TOTAL & $5.498^{*}$ \\
\hline
\end{tabular}

Dalam istilah lain bahwa data total global bisa jadi jauh lebih banyak dari pada yang ditangani. Jumlah yang disajikan IOM ada keterbatasan terkait dengan sistem entri data oleh relawan mereka. Juga kemampuan IOM memberikan bantuan terhadap individu-individu yang menjadi korban trafficking terbatas.

Untuk melihat data berdasar proporsi persen maka dapat dilihat dalam gambar berikut ini:

${ }^{*}$ Karena masalah yang disebutkan di atas double-entri, maka total regional dan global berhubungan dengan kesempatan individu mendapatkan bantuan yang diberikan oleh IOM untuk individu korban perdagangan orang yang mungkin terjadi, misalnya, di tempattempat tujuan dan asal. Jumlah individu yang dibantu oleh IOM secara global memang sedikit lebih rendah, IOM saat ini sedang mengerjakan finalisasi angka untuk jumlah total individu yang didampingi oleh IOM secara global.

18 “Iom 2011case Data on Human Trafficking: Global Figures \& Trends," hlm. 8. 


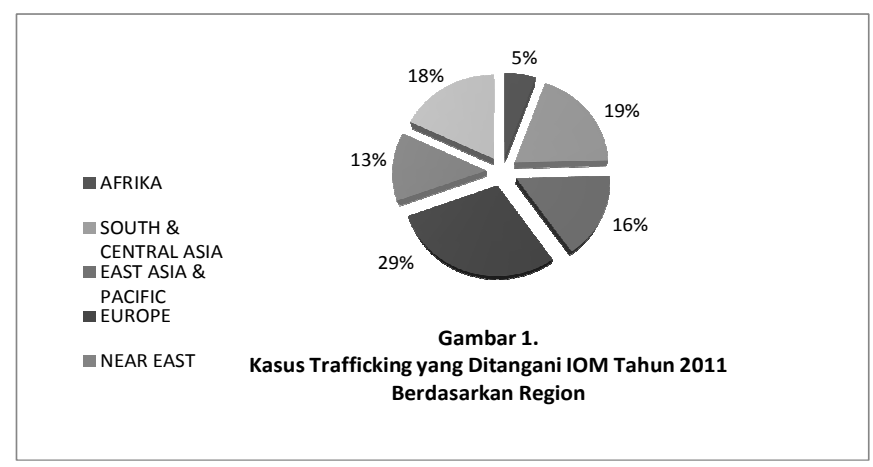

Berdasarkan data kasus trafficking global yang ditangani IOM yang berjumlah 5.498 tersebut di atas, dapat dijelaskan dalam kategori berdasarkan gender sebagai berikut: ada dua pertiga (62\%) dari korban trafficking adalah perempuan, separuh lebih dari jumlah perempuan korban trafficking merupakan laki-laki (37\%), dan jenis kelamin individu korban trafficking yang tidak diketahui jenis kelaminnya hanya satu persen (1\%) dari kasus. Sebagai gambaran dapat dilihat gambar 2 berikut: ${ }^{19}$

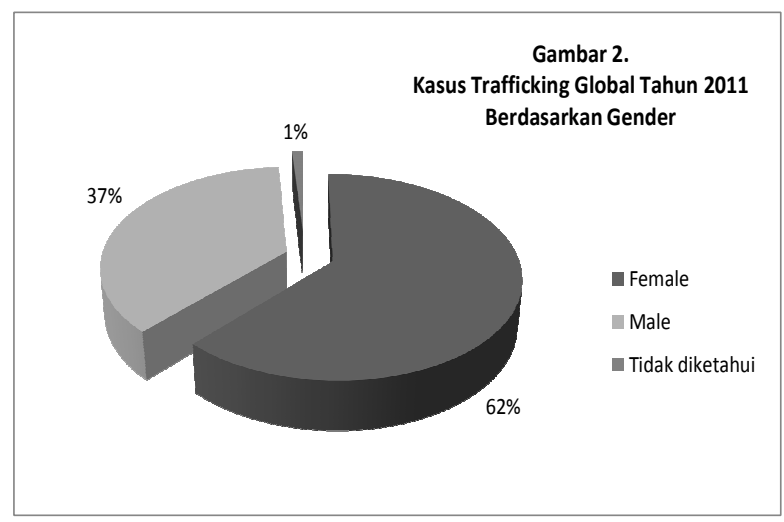

Sumber: Data Kasus Trafficking IOM

19 “Iom 2011case Data on Human Trafficking: Global Figures \& Trends," hlm. 5. 
Merujuk pada data dalam grafik di atas maka bisa terbaca bahwa perempuan merupakan kelompok masyarakat yang paling banyak menjadi korban trafficking global. Banyaknya perempuan yang menjadi korban trafficking menggambarkan terbukanya pekerjaan di luar rumah dan lingkungannya. Namun mereka mayoritas memiliki bargaining position yang lemah dalam relasi kerja atau di pasaran kerja menjadikannya mudah terjerat dalam penipuan atau bujuk rayu kelompok-kelompok mafia tenaga kerja. Kerentanan perempuan untuk menjadi korban trafficking dipengaruhi pula oleh rendahnya latar belakang pendidikan.

Sementara itu dari 5498 kasus global korban trafficking yang mendapatkan bantuan IOM pada tahun 2011. Berdasarkan usia korban dapat dijelaskan dalam 3 kategori; usia di atas 18 tahun, usia di bawah 18 tahun dan tidak diketahui usianya. Korban trafficking yang merupakan kategori orang dewasa berusia 18 tahun keatas, jumlahnya lebih dari setengah (62\%), mereka yang berkategori anak-anak atau usia di bawah 18 tahun jumlahnya sekitar 36\% dan yang tidak diketahui kategori usianya hanya sekitar dua persen (2\%). Sebagai gambaran dapat dilihat dalam gambar 3 berikut: ${ }^{20}$

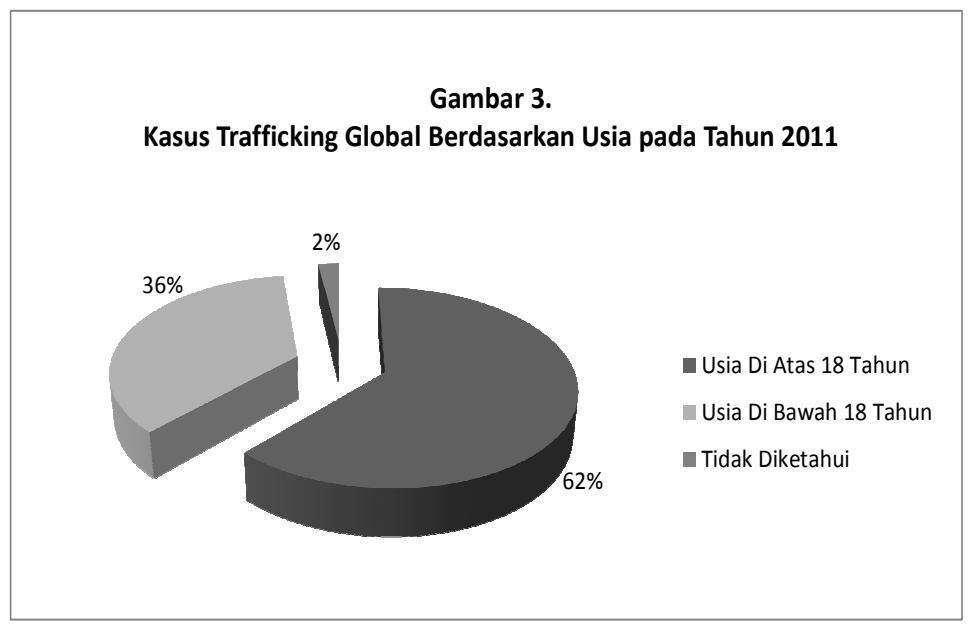

Sumber: Data Kasus Trafficking IOM

20 “Tom 2011 case Data on Human Trafficking: Global Figures \& Trends," hlm. 5. 
Merujuk pada grafik di atas maka bisa terbaca bahwa mayoritas atau setengah lebih mereka yang menjadi korban trafficking berusia produktif (usia di atas 18 tahun). Untuk korban trafficking dengan kategori anak-anak hanya sepertiganya. Kondisi ini menggambarkan pula bahwa dalam usia-usia produktifnya orang membutuhkan pekerjaan untuk memenuhi kebutuhan hidupnya dan posisi sosial di lingkungan masyarakatnya. Dalam rangka keduanya mereka rela dan berani bertaruh hidup, dengan mencari kerja di pasar gelap tenaga kerja atau terjebak dalam jerat penipuan.

Dalam konteks Indonesia trafficking merupakan problem kemanusiaan nasional. Ia terjadi diberbagai wilayah. Tidak hanya persoalan perkotaan tetapi juga perdesaan. Tidak hanya persoalan di Jawa tetapi juga berbagai pulau lainnya. Berdasarkan data dari Bareskrim Mabes Polri, dalam kurun waktu 2005-2009, Jabar menduduki peringkat atas kasus trafficking. Hal ini dapat terlihat dari data kasus dan korban yang terjadi di wilayah ini yang mencapai 794 kasus. Disusul kemudian Kalimantan Barat dengan 711 kasus dan Jawa Timur dengan 441 kasus. Adapun peringkat di bawahnya adalah Jawa Tengah dengan 404 kasus dan Nusa Tenggara Barat dengan 233 kasus. $^{21}$

Peluang terjadinya kasus trafficking pada warga negara Indonesia sangat tinggi. Kondisi ini mengacu pada jumlah warga Indonesia yang bekerja di luar negeri masih sangat tinggi, dengan perkiraan 6.500.000-9.000.000 pekerja migran Indonesia di seluruh dunia. Banyak dari pekerja sukarela bermigrasi tetapi kemudian dipaksa dengan prasyarat-prasyarat kasar.22 Besarnya jumlah pekerja migran tersebut secara ekonomi selama ini telah menjadi sumber devisa negara. Namun secara psikologis, fisik dan politis negara tidak cukup mampu memberikan jaminan keamanan dari mereka. Banyak dari mereka yang mengalami beragam kasus, diantaranya yang paling berat adalah korban trafficking.

\footnotetext{
${ }^{21} \mathrm{http}: / / \mathrm{www}$.gugustugastrafficking.org/index.php?option=com_content\&view=article\& id=1140:jabar-tertinggi-kasus-trafficking\&catid=134:info\&Itemid=152 unduh tanggal 13 juni 2013 jam 17.37.

22 US Department of State Trafficking in Persons Report, 2011.
} 
The International Organization for Migration (IOM) dan LSM anti-perdagangan terkemuka Indonesia memperkirakan bahwa 43 persen sampai 50 persen atau 3.000.000-4.500.000 tenaga kerja migran asal Indonesia yang menjadi korban yang mengindikasi perdagangan manusia (trafficking). Mereka berasal dari 33 provinsi di Indonesia yang merupakan sumber (dan tujuan internal migran) dari perdagangan manusia. Namun demikian beberapa daerah yang paling signifikan sebagai sumber korban trafficking, yaitu; Jawa, Kalimantan Barat, Lampung, Sumatera Utara, dan Sumatera Selatan. Mayoritas pekerja migran Indonesia menghadapi kondisi kerja paksa dan jeratan utang di luar negeri terutama negara-negara Asia yang lebih maju dan Timur Tengah, misalnya: Malaysia, Arab Saudi, Singapura, Kuwait, Suriah, dan Iraq. ${ }^{23}$

Sebagaimana data trafficking global tahun 2011 berdasarkan gender yang ditangani IOM, perempuan Indonesia merupakan kelompok yang sangat rentan terhadap perdagangan untuk eksploitasi seksual dan tenaga kerja. Diperkirakan bahwa antara 69-75 persen dari seluruh pekerja Indonesia di luar negeri adalah perempuan, sebagian besar bekerja sebagai pekerja rumah tangga. Jumlah perempuan Indonesia yang dilaporkan menjadi sasaran pemerkosaan saat bekerja sebagai pekerja rumah tangga di 2010 tampaknya meningkat. Berdasarkan survei tahun 2010, sebuah LSM Indonesia yang memiliki reputasi baik, mencatat bahwa 471 migran Indonesia kembali dari Timur Tengah hamil akibat perkosaan, dan 161 tambahan kembali dengan anak-anak yang lahir di Timur Tengah. ${ }^{24}$

\section{E. Strategi Melawan Trafficking}

Strategi melawan trafficking yang paling awal dan penting adalah penguasaan atau ketersediaan data tentang kasus ini secara komprehensif. Memiliki data sangat penting untuk membuat keputusan dalam merancang, merancang ulang, meninjau, merevisi atau memperbarui proyek penanggulangan perdagangan orang. Informasi yang valid dan dapat diandal-

${ }^{23} 2011$ US Department of State Trafficking in Persons Report.

${ }^{24} 2011$ US Department of State Trafficking in Persons Report. 
kan, memberikan wawasan yang bermanfaat untuk memahami latar belakang dan mekanisme dari proses perdagangan manusia. Informasi tersebut juga dapat membantu mengidentifikasi kesenjangan dan kebutuhan dalam pemberian bantuan, yang dapat mempengaruhi perumusan dan implementasi tindakan yang ditargetkan untuk memperbaiki kondisi. Data dan pemantauan dapat membantu membentuk sebuah proyeksi situasi yang mungkin memerlukan tindakan koreksi, mengidentifikasi kesenjangan atau menyoroti sesuatu yang berlangsung baik dan perlu diulang atau ditiru ${ }^{25}$.

Trafficking merupakan masalah global yang bisa jadi menakutkan bagi pemerintah, pembuat kebijakan dan organisasi yang membantu para korban. Melawan mafia perdagangan manusia tidaklah mudah karena mereka terorganisir rapi, memiliki financial yang kuat, dan mampu mempengaruhi kekuasaan politik pada berbagai level. Ada 3 strategi yang efektif yang bisa dilakukan, yaitu:

\section{Pencegahan}

Kegiatan pencegahan sangat penting dalam memerangi perdagangan manusia. Dilakukan dengan cara negara asal dapat memberikan alternatif bagi pekerja yang amat rentan terhadap perdagangan orang, berupa negara transit untuk memperkuat kontrol perbatasan dan melatih para pejabat yang memungkinkannya mengidentifikasi sub-kelompok orang yang diperdagangkan dalam kelompok migran yang lebih besar yang bergerak melalui negara mereka, secara legal atau ilegal. Negara tujuan mengawasi eksploitasi yang terjadi di perbatasan mereka, dan memperkuat hak-hak buruh migran, atau memfasilitasi arus hukum pekerja migran untuk mengurangi permintaan terhadap migran gelap. Negara-negara dengan masalah trafficking internal harus memperkuat pendidikan atau membuat program kerja pada masyarakat yang rentan.

Mengacu pada Undang-undang Republik Indonesia Nomor 21 Tahun 2007 tentang Pemberantasan Tindak Pidana Perdagangan Orang, Pasal 56

${ }^{25}$ Lihat dalam International Organization for Migration, Handbook on Performance Indicators for Counter-Trafficking Projects, 1752 N Street NW, Suite 700 Washington, DC 20036 United States of America, hlm. 1. 
bahwa pencegahan tindak pidana perdagangan orang bertujuan mencegah sedini mungkin terjadinya tindak pidana perdagangan orang. Pihak-pihak yang bertanggungjawab dalam hal pencegahan termaktub dalam Pasal 57 yaitu; Pemerintah, Pemerintah Daerah, masyarakat, dan keluarga wajib mencegah terjadinya tindak pidana perdagangan orang. Pemerintah dan Pemerintah Daerah wajib membuat kebijakan, program, kegiatan, dan mengalokasikan anggaran untuk melaksanakan pencegahan dan penanganan masalah perdagangan orang.

\section{Perlindungan}

Perlindungan korban merupakan bagian penting dari setiap penanggulangan perdagangan orang. Perlindungan meliputi perlindungan segera bagi para calon atau yang diidentifikasi korban perdagangan manusia, menjaga mereka dalam posisi aman selama pemenuhan kebutuhan dasar mendesaknya (misalnya; penampungan, medis, psikologis dan psikososial perawatan, makanan dan pakaian). Selanjutnya, perawatan sementara dan pemulangan dan reintegrasi/integrasi sebagai pilihan yang harus didiskusikan. Ini termasuk pilihan untuk pemukiman di daerah, negara ketiga tujuan atau di bagian lain dari negara asal korban yang sesuai. Menjaga korban aman juga membutuhkan tingkat kerahasiaan yang tinggi ketika mengelola kasus - identitas korban harus dilindungi. Hal ini penting tidak hanya untuk melindungi korban dan penyedia layanan dari penyelundup, tetapi juga untuk melindungi korban dari stigma yang potensial di keluarga atau masyarakat mereka. ${ }^{26}$

Perlindungan juga berarti menciptakan lingkungan (sosial, politik dan hukum) yang mendorong perlindungan korban perdagangan manusia. Diantaranya menciptakan visa sementara atau permanen khusus yang memungkinkan korban dari negara lain untuk tetap legal di negara tujuan (sebagai bentuk kerjasama antar pemerintah). Undang-undang yang sesuai dapat digunakan tidak hanya untuk menuntut pelaku trafficking, tetapi juga

${ }^{26}$ International Organization for Migration, Handbook on Performance Indicators for Counter-Trafficking Projects, hlm. 5. 
untuk melindungi korban. Akses ke bantuan sistem peradilan korban merupakan kesempatan untuk keadilan dan kompensasi. Penekanan harus diberikan kepada fakta bahwa korban perdagangan manusia adalah korban dari kejahatan dan harus diakui dan diperlakukan seperti itu - bukan sebagai kejahatan atas diri sendiri. ${ }^{27}$

\section{Penuntutan/penindakan}

Menindak trafficker adalah hal lain bagian penting dari strategi yang komprehensif untuk memerangi perdagangan manusia. Penguatan legislasi dan kebijakan untuk menahan penyelundup jawab atas kejahatan mereka perlu untuk memiliki efek pada pedagang. Di beberapa negara, aset penyelundup disita dan digunakan untuk membiayai proyek-proyek bantuan untuk korban. Kerja sama internasional sangat penting, terutama ketika kejahatan adalah bersifat transnasional ${ }^{28}$.

Mengacu pada pengalaman IOM dalam menangani perdagangan manusia, perlu didekati dalam konteks keseluruhan pengelolaan migrasi. Untuk itu perlu kemitraan dengan lembaga pemerintah, LSM dan organisasi internasional. Pendekatan ini didasarkan pada tiga prinsip yang mengatur semua kegiatan penanggulangan perdagangan orang, yaitu: ${ }^{29}$

a. Menghormati hak asasi manusia.

b. Meningkatkan kesejahteraan fisik, mental dan sosial individu dan komunitasnya.

c. Keberlanjutan melalui peningkatan kapasitas kelembagaan pemerintah dan masyarakat sipil.

\section{F. Simpulan}

Migrasi internasional merupakan fenomena global yang cenderung meningkat seiring perkembangan jaman. Banyak faktor yang mempe-

\footnotetext{
${ }^{27}$ International Organization for Migration, Handbook on Performance Indicators for Counter-Trafficking Projects, hlm. 5.

28 International Organization for Migration, Handbook on Performance Indicators for Counter-Trafficking Projects, hlm. 6.

${ }^{29}$ US Department of State Trafficking in Persons Report, 2011.
} 
ngaruhinya, kemajuan ilmu pengetahuan dan teknologi menjadi faktor yang menentukan serta perubahan struktur demografi global. Latar belakang migrasi pun cukup beragam dari masalah politik, agama, psikologi dan ekonomi. Namun demikian tujuan ekonomi merupakan aspek yang dominan. Harapan untuk meningkatkan kesejahteraan hidup menjadi citacita setiap pekerja migran. Adanya daerah tujuan yang memberikan harapan kehidupan yang lebih baik menjadi daya tarik. Kondisi kehidupan yang buruk atau kemiskinan di daerah asal menjadi daya dorong untuk migrasi. Namun demikian tidak semuanya bisa mencapai tujuannya. Banyak dari mereka karena kerentanannya yang terjebak dalam mafia pekerja internasional. Banyak pekerja migran yang masuk dalam jaring-jaring mafia yang akhirnya menjadi komodtas yang menguntungkan. Orangorang yang terjebak dalam mafia pekerja tersebut dalam istilah menjadi korban trafficking. Gejala trafficking terjadi pada semua negara di duania, baik negara maju maupun terbelakang. Oleh karenanya trafficking dalam pandangan penulis merupakan sisi buram dari migrasi internasional. Munculnya trafficking dalam proses migrasi internasional, sebagai akibat dari adanya nilai ekonomis tinggi dalam usaha ini. Kuatnya mafia trafficking, harus dilawan dengan cara-cara yang efektif melalui; pencegahan, perlindungan dan penindakan. Kerjasama dalam kemitraan antara pemerintah, LSM dan masyarakat menjadi kekuatan tersendiri. Pencegahan sejak dini bisa dilakukan dengan meningkatkan kesejahteraan ekonomi masyarakat, meningkatkan pendidikan dan keterampilan pada masyarakat usia kerja, pemberian informasi yang lebih baik tentang peluang kerja di daerah lain atau luar negeri. Kerjasama antar negara asal dan tujuan secara bilateral atau multilateral merupakan langkah politik yang strategis. Penindakan terhadap terhadap pelaku trafficking dengan memberikan hukuman yang berat akan mengurangi, ruang gerak mafia pekerja internasional. Melindungi mereka-mereka yang telah keluar dari jaring-jaring mafia menjadi tanggungjawab semua pihak negara, $1 \mathrm{sm}$, dan masyarakat luas. Bagaimana pun melarang orang untuk bermigrasi karena alasan ekonomi atau lainnya jelas tidak mungkin, karena akan melanggar hak-hak asasi manusia setiap warga negara.] 


\section{Daftar Pustaka}

Bonasahat, Albert, S.H., LL.M., ILO Jakarta, Briefing Jurnalis: Catatan Akhir Tahun Perlindungan Pekerja Migran, http://www.ilo.org/wcmsp5/ groups/public/-asia/--ro-bangkok/-ilo-jakarta/documents/presentation/ wcms_201585.pdf unduh Rabu, 25 Desember 2013, jam 07.05.

Counter-Trafficking; IOM's Approach, lihat dalam http://www.iom.int/ cms/countertrafficking jam 17.45, 13 Juni 2013.

Haris, Abdul, Gelombang Migrasi dan Jaringan Perdagangan Manusia, Yogyakarta: Pustaka Pelajar, 2005.

http://www.gugustugastrafficking.org/index.php?option=com_content\&view=art icle\&id=1140:jabar-tertinggi-kasus-trafficking\&catid=134:info\&Itemid $=152$ unduh tanggal 13 juni 2013 jam 17.37.

International Labour Organization (ILO), Jakarta, 10 Tahun menangani migrasi kerja di Indonesia, http://www.ilo.org/wcmsp5/groups/public/--asia/-ro-bangkok/--ilo-jakarta/documents/publication/wcms_213360.pdf, unduh Selasa, 24 Desember 2013, jam 05.54.

International Organization for Migration, Handbook on Performance Indicators for Counter-Trafficking Projects, 1752 N Street NW, Suite 700 Washington, DC 20036 United States of America.

IOM 2011case Data On Human Trafficking: Global Figures \& Trends, The data in this document was complied by IOM Headquarters staff, Anvar Serojitdinov, Project Officer, aserojitdinov@iom.int in conjunction with the assistance of IOM field missions. All enquiries can be addressed to the given email address or directly to the appropriate IOM mission.

Massey, Douglas S., "Patterns and Processes of International Migration in the 21st Century", Paper prepared for Conference on African Migration in Comparative Perspective, Johannesburg, South Africa, 4-7 June, 2003.

The Hypothesis of the Mobility Transition Author(s): Wilbur Zelinsky, Source: Geographical Review, Vol. 61, No. 2, Apr., 1971.

Theories of International Migration: A Review and Appraisal, Author(s): Douglas S. Massey, Joaquin Arango, Graeme Hugo, Ali Kouaouci, Adela Pellegrino, J. Edward Taylor, Source: Population and Development Review, Vol. 19, No. 3 , Sept., 1993. 
Undang-Undang No. 21 tahun 2007 tentang Pemberantasan Tindak Pidana Perdagangan Orang.

US Department of State Trafficking in Persons Report, 2011. 